IZA DP No. 8999

Is Rationing in the Microfinance Sector Determined by the Microfinance Type? Evidence from Ghana

Luis Diaz-Serrano

Frank G. Sackey

April 2015 


\title{
Is Rationing in the Microfinance Sector Determined by the Microfinance Type? Evidence from Ghana
}

\author{
Luis Diaz-Serrano \\ CREIP, Universitat Rovira i Virgili \\ and IZA \\ Frank G. Sackey \\ CREIP, Universitat Rovira i Virgili
}

Discussion Paper No. 8999

April 2015

IZA
P.O. Box 7240
53072 Bonn
Germany

Phone: +49-228-3894-0

Fax: +49-228-3894-180

E-mail: iza@iza.org

Any opinions expressed here are those of the author(s) and not those of IZA. Research published in this series may include views on policy, but the institute itself takes no institutional policy positions. The IZA research network is committed to the IZA Guiding Principles of Research Integrity.

The Institute for the Study of Labor (IZA) in Bonn is a local and virtual international research center and a place of communication between science, politics and business. IZA is an independent nonprofit organization supported by Deutsche Post Foundation. The center is associated with the University of Bonn and offers a stimulating research environment through its international network, workshops and conferences, data service, project support, research visits and doctoral program. IZA engages in (i) original and internationally competitive research in all fields of labor economics, (ii) development of policy concepts, and (iii) dissemination of research results and concepts to the interested public.

IZA Discussion Papers often represent preliminary work and are circulated to encourage discussion. Citation of such a paper should account for its provisional character. A revised version may be available directly from the author. 
IZA Discussion Paper No. 8999

April 2015

\section{ABSTRACT}

\section{Is Rationing in the Microfinance Sector Determined by the Microfinance Type? Evidence from Ghana}

This study sets out to examine the extent to which access to credit and credit rationing are influenced by the microfinance type based on the major factors determining micro, small and medium enterprises' access to credit from microfinance institutions in the era of financial liberalization. The data for the study were gleaned from fourteen microfinance institutions' credit and loan records consisting of borrowers and credit characteristics. Our results are puzzling and show that credit rationing is not influenced by the microfinance types but by the individual microfinance institutions.

JEL Classification: G21

Keywords: $\quad$ microfinance, Ghana, credit rationing

Corresponding author:

Luis Diaz-Serrano

CREIP - Universitat Rovira i Virgili

Department of Economics

Av. Universitat 1

43204 Reus

Spain

E-mail: luis.diaz@urv.cat 


\section{Introduction}

Ghana's micro and small enterprises (MSEs) employ about 80\% of the working population in the private sector. This sector is characterized by the difficulty in accessing the credit required to expand, boost production and increase employment and incomes. The main reason for this difficulty is that the microfinance institutions that are set up to provide the necessary credit engage in credit rationing. A major problem that remains a puzzle in trying to overcome this difficulty is determining the extent and nature of this credit rationing across the microfinance types. The research aims to test the extent and degree of rationing across the microfinance types in Ghana. It will therefore test for the significance of the firm, loan and borrower characteristics in determining credit rationing. This is necessary because of the likelihood of the credit-rationing problem differing across microfinance types and therefore there is a need not only to view the problem holistically but also to consider it based on the institutional type so that it can be resolved effectively.

The introduction of the financial reforms in 1989 in Ghana triggered massive growth in the financial sector, as witnessed by the increase in the number of commercial banks, which has led to competition and market efficiency. However, these commercial banks charge high interest rates (between $24 \%$ and $30 \%$ per annum) and consider the amount of the loans required by these micro and small businesses too small in relation to the cost of lending. Another problem faced by these micro and small businesses is that the requirements for accessing loans from the commercial banks are too cumbersome (Economic Reforms in Ghana: Miracles and Mirage, 2000).

Over the past decade and since the United Nations declared 2005 as the International Year of Micro Credit, much recognition has been given to microfinancing as a means of bridging the credit gap created by commercial banks. Microfinance institutions 
(MFIs) have undergone various phases and currently four major types exist in Ghana. These are non-governmental organization microfinance, rural and community banks, savings and loans companies and government-sponsored microfinance. The microfinance sector in Ghana has witnessed growth in outreach as well as in the number of registered and non-registered microfinance institutions. The sector served over 5.4 million clients as of December 2010 (GHAMFIN, 2011). The Bank of Ghana (BOG), by the end of October 2012, had registered a total of 161 MFIs and granted them a provisional license (BOG, 2012). The challenge, however, is that the growth of the industry is yet to reflect the scope of microfinance products available for microfinance clients (Ayeh, 2012). A major problem faced by these micro and small entrepreneurs is that they are unsure which of these microfinance institutions would give them the credit needed for their operations since they perceive these MFIs as not different from commercial banks. It must be emphasized that though these microfinance institutions' operations are guided by the Ghana Microfinance Policy (GHAMP), their individual policies and modes of operation often deviate from it as they frequently request various pieces of information from borrowers as the basis for granting loans. The applicants are therefore not certain which part of the information required by these institutions in the loan processing will ensure that the credit needed will be granted. Another problem that is of great concern is that these microfinance institutions charge interest rates that are even higher than those charged by commercial banks. It was the intention that these MFIs would charge interest rates that are lower and affordable by micro and small businesses, but whereas commercial banks charge annual interest rates ranging from $21 \%$ to $30 \%$, microfinance institutions charge annual rates ranging from $24 \%$ to $60 \%$. Though MSEs are seen as risky, high interest rates are used to make up for the defaults; this nonetheless has not reduced the number of desperate applicants who are considered to be risky demanding credit from this credit market. Understanding 
microfinance as a financial transaction with MSEs and as a tool for development is the key to ensuring sustainable private sector growth and the growth of the economy as a whole.

The study will test the hypothesis that credit rationing is influenced by the microfinance type. It will determine the extent to which, once we control for firm and borrower characteristics, the microfinance type still plays a role in determining credit rationing. The outcome of this research will therefore offer policy recommendations to the various microfinance institutions for addressing the problem of credit rationing effectively.

\section{Theoretical Framework}

Credit rationing is a situation in which borrowers are given just some or none of the amount they request from lenders even though they are willing to pay the market rates of the cost of borrowing (interest rates). This basically occurs as a result of the existence of information asymmetry. It is therefore a situation in which the equilibrium price (interest rate) does not ensure efficient allocation of credit; hence, rationing is performed instead of allocation using a non-price mechanism. The studies by Jaffee and Russell (1976) and Stiglitz and Weiss (1981) demonstrated that the difficulty in gaining access to credit might persist even in equilibrium markets using information-based models. To them interest rates cannot function as an allocator of credit in so far as information asymmetries exist and therefore credit rationing may persist even in the face of interest rate liberalization. Stiglitz and Weiss (1981) argument was in disagreement of the interest rates liberalization proponents of McKinnon (1973) and Shaw's (1973) that when interest rates are liberalized financial markets will allocate credit based on the interest rates that reflects scarcities. Despite these theoretical efforts, there remains little consensus about whether this 
difficulty with regard to access to credit is an economically significant phenomenon. Whereas Riley (1987) argued that this difficulty in the Stiglitz-Weiss environment is limited to the marginal class of distinct risk pools, Stiglitz and Weiss (1987) counter argued that Riley's result is model-specific rather than general. Others have argued that contractual mechanisms, such as loan commitments (Boot and Thakor, 1989; Sofianos et al, 1990) and collateral (Bester, 1985; Chan and Kanatas, 1985) may mitigate the problem of access to credit. The significant effect of information asymmetry on credit access is largely accepted in the literature; however, given the arguments on all sides of this issue, it is clear that there are competing theories on the persistence of difficulty in gaining access to credit and these render the explanations for access to credit inconclusive.

Empirical studies seeking to test these competing theories have made a better job of explaining such a phenomenon; however, very few such studies exist in this regard. Those that do exist either paid little attention to the credit-rationing problem or were unable to explain adequately the credit constraints facing micro and small enterprises (Akoten et al, 2006; Petrick, 2005). There is also an absence of studies that holistically tested various theories that attempt to explain access to credit.

While financial loans are sticky, unable to adjust quickly to changes in the openmarket rates, which is consistent with credit allocation, this stickiness varies with loan contract terms in ways that are not predicted by equilibrium credit markets. It must be emphasized that interest rates are often fixed by the various microfinance institutions and are set very high to discourage less profitable businesses from applying for loans even before the credit-rationing processes begin. Our sample shows large differences in the interest rates depending on the institution type. 
Access to credit and credit rationing may differ according to the MFI type since the MFIs may be differentiated by their lending policies, mission drift, organizational form and institutional transformation as well as by their disclosure and transparency (Akoten et al, 2006; Von Pischke, 2008). Again, these are issues that have not been empirically studied to a large extent and warrant further investigation. It is clear that access to credit by micro and small enterprises is difficult but the extent and severity of this phenomenon are unknown. This situation therefore calls for an empirical estimation to determine the extent to which loan, firm and borrower characteristics determine the access to credit and rationing of credit in microfinance and the extent to which institutional factors influence the rationing and credit access. Various researchers have reached the conclusion that credit rationing exists in most developing countries even in the face of interest rate liberalization (Okerenta et al, 2005; Rahji et al, 2009; Zeller, 1994; Zeller et al, 2002). According to Duong and Izumida (2002), the terms and conditions under which credit is transacted vary substantially based on the characteristics of the borrower and the lender and the relationship between them. In other words, borrower-lender variables determine the terms of a credit contract.

Since credit markets are characterized by imperfect information and high costs of contract enforcement, an efficiency measure that exists in a perfectly competitive market will not be an accurate measure against which to define market failure. The problems leading to credit rationing in credit markets in developing countries are basically the problems of adverse selection and moral hazard. Adverse selection arises because in the absence of perfect information about the borrower, an increase in interest rates encourages the borrowers with the most risky projects, hence those who are least likely to repay, to borrow, whilst those with the least risky projects cease to borrow. Interest rates will thus 
not play the allocative role of equating demand and supply for loanable funds and will affect the average quality of lenders' loan portfolios. Moral hazard occurs basically because projects have identical mean returns but different degrees of risk, and lenders are unable to discern the borrowers' actions (Besley, 1994; Stiglitz and Weiss, 1981).

According to Atieno (2001), the problem of access to credit is one created by the institutions mainly through their lending policies. Schmidt et al (1987) observed that lending policies affecting access to credit are often displayed in the form of minimum loan amounts, complicated application procedures and restrictions on credit for specific purposes. Schmidt et al (1987) argued that the type of financial institution and its policy determine access to credit. Atieno (2001) further observed that the lending terms and conditions imposed by lenders, such as the application fee, collateral value, application period, repayment period and purpose, influence the enterprise's decision on whether to apply for credit or not as well as to which type of MFI to apply. Aquire et al (2011) found that MFIs may adopt different policies, such as solidarity group lending, which includes the Grameen Bank model and the Latin American model, individual lending, the village banking model and the credit union model, and all of these tend to affect access to credit. Aquire et al (2011) further observed that MFIs' policy often hinges on areas of operation, borrowers' eligibility, eligible projects, loan maturity periods, business operations, interest rates, collateral, loan limits, credit contracts and secrecy of information, which tend to affect access to credit. According to Hardy et al (2002), a microfinance institution's commitment may be replaced or supplement other private or public objectives, such as maximizing share value, the direction of investment in priority sectors or the mobilizing of savings to finance government operations, and this may greatly affect credit access. Since microfinance operations are influenced by their institutions and policies, source of funding 
and objectives, it is possible that their rationing behavior may differ based on the microfinance institutional type. It is for these reasons that we find it pertinent to determine the extent to which credit rationing is determined by the microfinance institution type.

\section{Review of the Empirical Literature}

Various studies have been conducted in the area of access to credit and credit rationing. The results, however, show strong and significant relationships with the loan, firm and borrower characteristics as well as mixed results for some of them. It is relevant and imperative, however, to distinguish between studies conducted in developed countries and those conducted in developing countries, since the institutional, legal and development nature of the financial sectors as well as the business environments differ among these countries.

\subsection{Studies from Developed Countries}

In their study determining the factors affecting credit rationing using 6,250 UK firms in the 2004, 2008 and 2009 Survey of Small- and Medium-Sized Enterprises' Finances, Armstrong et al (2013) observed that firm characteristics were the major determinants of credit rationing, with firms with a higher credit risk rating, previous financial delinquency and lower sales more likely to be rejected whilst older and more established businesses were less likely to face rejection. Using credit information on 56,752 firms between 1993 and 2008 from the Spanish Banking Association (AEB) and the Spanish Confederation of 
Savings and Banks (CECA), Carbo-Valverde et al (2011) found that firms with more intense lending relationships, as measured by the lower number of banks that they dealt with, enjoyed a greater supply and a lower degree of credit rationing. Becheti et al (2009) noticed that the borrower's past record was significant in determining credit rationing, whilst the number of pre-existing loans with other banks and the loan duration were also significant but negatively correlated with the supply of credit, using a sample of 1,009 Italian loan applicants from the official bank records of Banca Etica for the period 1999 to 2006. Using a sample of 2,698 SMEs reporting data over the period 1993-2001 in Belgium, Steijvers (2008) found that applicants for long-term bank credit were rationed more than those applying for short-term bank credit. He also noticed that the firms that applied for credit and were rationed were firms that were smaller in terms of size and had a low return on assets.

When determining credit rationing for 1,140 business starters in the Dutch County South Limburg for the period 1998-1999, Blumberg and Latterie (2008) observed that credit denial largely depended on entrepreneurs' commitment and signals regarding the repayment of the loan and the success chances of the proposed business. In a similar study conducted by Atzeni and Piga (2007) on 3,144 firms in Italy, the authors concluded that the probability of being denied credit was high for firms with no or low research development intensity. Thus, the credit constraints were severe for innovation firms. When determining access to credit for corporate farmers in the 2003 BASIS Survey in Russia, Subbotin (2005) observed that farm specialization and profitability were significant and positive. Using a sample of more than 3 million loan applicants between 1998 and 2000 from the Spanish Credit Register (Central de information de Riesdos or CIR), Jimenez and Saurina (2003) observed that the bank-borrower relationship was an important factor in 
determining access to credit. Based on the US Survey of Consumer Finance of 1998, involving a sample of 2,733 applicants, Chakravarty (2002) found that relationship variables were very important determinants of credit rationing. In a study on the evidence concerning the empirical significance of credit rationing using 1,103 borrowers, with 933 independent observations from the Federal Reserve's survey of terms of bank lending in the United States between 1977 and 1988, Berger et al (1999) discovered that commitment borrowers were not rationed whilst non-commitment borrowers were rationed.

The above studies show that firm characteristics, such as firm size, return on assets and profitability, are vital and important in determining credit rationing, whilst borrower characteristics, such as the borrower-lender relationship and past record, also play significant roles in determining credit rationing. With regard to loan characteristics, the duration of the loan repayment period is an important determinant with a preference for short-term loans determining a lower likelihood of being rationed.

\subsection{Studies from Developing Countries}

Access to credit by MSMEs in developing countries has become very challenging and many efforts to face this challenge are being made. It is therefore not surprising that contemporary research has paid much attention to this area.

Using a sample of 4,300 financially distressed SMEs to determine the factors influencing the access to credit in Croatia, Ana et al (2011) observed that enterprise size was significant in determining credit rationing and that having a relatively larger enterprise size reduced the likelihood of being rationed. Investigating credit rationing by commercial banks in Ghana using 178 SMEs for the period 2000-2004, Ahiawodzi et al 
(2010) noticed that higher interest rates, lower maturity of loan repayment, a higher value of assets, experience and higher profits reduced the probability of being rationed. Using a sample of 411 applicants in the Peri-Urban District in Ho Chi Minh City of Vietnam, Doan et al (2010) found that wealthier households, in terms of asset holding and mobile phone possession, and the distance to the nearest banks were the significant factors determining credit rationing. Using a sample of 1,076 respondents from 34 randomly selected villages in Bangladesh, Chakravarty et al (2010) observed that respondents who built a longer membership with a micro credit provider and had non-mandatory savings accounts and a track record of payments of previous loans were more likely to apply and be approved.

With the aim of determining the access to credit and borrowing behavior of rural households in a transition economy using data from the Vietnam Living Survey (VLSS) for the period 1992/93 and 1997/98, Nguyen (2007) observed that the age of the household head and the working adult rate had a positive and significant relationship with access to credit, whilst the distance to the bank was negative and significant in determining access to credit. Similar research was conducted by Lawal et al (2009), using 150 randomly selected cocoa farming households in Nigeria, and they observed that requests for collateral and the gender of the household head increased the constraints to access to credit, whilst the educational status, years of experience and presence of savings reduced the constraints to access to credit. Nuryartono et al (2005) also conducted similar research using 63 households in rural areas of Central Sulawesi in Indonesia. They observed that human capital (education and age) as well as wealth and risk-bearing indicators (distance from the house to the road) were significant in determining credit constraints. Using a sample of 290 borrowers from 20 formal and informal financial institutions operating in the Niger Delta of Nigeria, Okerenta and Orebiyi (2005) found that access to credit was determined 
by the profitability level, value of assets and interest rates and that the higher these were, the less likelihood there was of being denied access to credit. Similarly, in determining access to credit and the loan amount, using the Fourth Round Ethiopian Urban Survey involving 1,500 households for the 2000 period, Kedir (2000) observed that the geographical location, value of assets, value of collateral, number of dependents and marital status as well as outstanding debts were significant factors determining credit rationing. The above studies from developing countries show that for firm characteristics, a higher value of assets, higher profits and the value of collateral feature prominently in reducing the likelihood of credit being rationed, whilst with regard to borrower characteristics, longer years of experience in business, a desirable borrower-lender relationship, past records, the distance of the borrower to the lending institution and the educational status are the important factors reducing the likelihood of being rationed. Concerning the loan characteristics, higher interest rates, a shorter maturity loan period and having non-mandatory savings are the important factors that reduce the likelihood of being rationed.

\subsection{Studies from Developed and Developing Countries Compared}

The empirical studies in both developed and developing countries have shown that credit rationing exists among micro, small and medium enterprises across the various countries. The various studies show that both the developed and the developing countries use firm, borrower and loan characteristics in determining credit rationing, but the use of borrower characteristics in rationing credit is more severe in developing countries than in developed countries. This may be due to the fact that the financial sector in the developed countries can boast a fairly enabling environment and a strong legal system, which tend to reduce 
the default risk, thereby reducing credit rationing, whilst the unavailability of credit bureaus in developing countries may account for the severe nature of the rationing problem. As we will observe in the empirical analysis, our results show that individual, firm and loan characteristics influence the credit-rationing behavior of the various microfinance institutions in Ghana.

\subsection{Institutional Framework}

To understand fully the credit-rationing problem and the factors influencing the creditrationing behavior of the microfinance institutions in Ghana and Africa as a whole, it is pertinent to discuss the nature, characteristics, policy guidelines and mode of operations of these microfinance institutions so that the credit-rationing problem can be addressed holistically.

Financial inclusion has been uneven across African countries. Whereas some countries, such as Kenya and Uganda, have been successful, other countries, such as Liberia and Namibia, are extremely underdeveloped, especially in the microfinance market. African microfinance is distinguished by the availability of financial service providers, ranging from cooperatives, community-based models and non-governmental organizations to commercial banks and savings and postal banks. This is due to the nature of the financial system in Africa and thereby influences the role of its stakeholders in the continent and its impact. A large number of informal sector intermediaries and individuals who provide financial services, such as the tonties in Cameroun, the banquiers ambulants in Benin and the susu in Ghana, have taken root in African countries. These providers charge large interest rates on loans administered mainly to poor people who conduct 
business in the informal sector. They operate largely without formal recognition in terms of licenses and registration. Because of their nature, they have few opportunities to grow and expand (UN, 2011). Another type of microfinance provider is the credit unions, which provide savings and credit services to their members and occasionally to non-members but at different interest rates. Membership is essentially based on the principle of a common bond, such as the workplace, the community or producers of a particular commodity. Also known as savings and credit cooperative organizations (SACCOs), they have grown significantly in Africa. Non-governmental MFIs are another type, normally affiliated with international NGO networks and offering services for humanitarian or social reasons. As a way of ensuring their sustainability, however, they are increasingly becoming more finance and profit driven. Also operating in Africa are rural and community banks, which are well established in countries such as Ghana, Nigeria, Tanzania and Sierra Leone. Microfinance banks, mostly found in Southern Africa and Nigeria, are another type of microfinance institution. They are often regulated by commercial banks and offer a broad range of services and products. The market structure of microfinance institutions across Africa has been changing over the past few years, as more of the non-profit MFIs are now changing to a profit-based structure. All the institutional types of MFIs offer voluntary savings products. Most loans are classified either as microenterprise or as household loans and have terms of usually less than two years (Mix, 2011). The institutional differences across sub-regions are partly explained by the specificities of the microfinance laws governing them.

Despite the remarkable successes achieved by some African countries in the role played by their MFIs, there are major constraints that hinder their growth. In most countries, the lack of capacity is most acute, especially at the retail level, which is the 
backbone of the financial system. The operational costs are high, making it difficult to extend services on a large scale. There is also excessive government intervention in terms of regulatory issues, some of which harm the development of microfinance in some African countries, especially interest rate ceilings, which do not allow the microfinance institutions to set their own interest rates to be able to maximize their profits. In countries where microfinance performance is not encouraging, these countries have financial sectors that are not fully liberalized, whilst in the countries where the financial sector has been liberalized, borrowers face severe rationing and high interest rates. The tax regime, for instance, remains unclear, unfair or both. For example, fiscal advantages may be offered to charter types such as cooperatives, but not to other institutional types.

Microfinance in Ghana has passed through four distinct phases. The first phase, which started in the 1950s, involved the provision of subsidized credit by the Government. The second phase was the provision of microcredit to the poor through NGOs in the 1960 s and 1970s. During this phase, sustainability and financial self-sufficiency were not considered important. The third phase saw the formalization of microfinance institutions, which began in the 1990s. The fourth phase, the current phase, involves the commercialization of microfinance institutions. This started in the mid-1990s and gained much importance with the mainstreaming of microfinance and its institutions in the financial sector. According to Aryeetey et al (2000), the microfinance institutions in Ghana belong to the informal financial markets, which are basically fragmented, faced with information asymmetries and often grant small, short-term loans to risky borrowers who are already rationed out of credit from the formal financial sector.

The term microfinance institution in Ghana is understood as a sub-sector of the financial sector, comprising most different financial institutions that use a particular 
financial method to reach the poor. The microfinance sector in Ghana comprises four tiered ranges: formal suppliers, which include the savings and loan companies and rural and community banks; semi-formal suppliers, including credit unions, financial nongovernmental organizations (FNGOs) and cooperatives; informal suppliers, including susu collectors and clubs and rotating and accumulating savings and credit associations (ROSCAs and ASCAs); and government-sponsored microfinance schemes and programs, which have also been instigated, the current scheme being the Micro and Small Loans Centre (MASLOC).

In Ghana, the clients of microfinance are predominantly women in both rural and urban centers. These women are engaged in activities such as farming, food processing, petty trading, service provision and street vending. It is known that loans advanced by microfinance institutions are normally for purposes such as housing, petty trade and as "start-up" loans for farmers to buy inputs for farming, including rice seeds, fertilizers and other agricultural tools; some of the loans are used for a variety of non-crop activities, such as dairy raising, cattle fattening, poultry farming, weaving, basket making, leasing farm and other capital machinery and woodworking. Microfinance loans may also be used for a number of other commercial activities, including cloth trading, pottery manufacturing, wholesaling and retailing. Microfinance institutions have been grouped into four main types based on their nature, mode of registration and operations, sources of funding, capital requirements and depth of outreach. Microfinance institutions in Ghana are registered and operated under the supervision of the Bank of Ghana and are guided by the Ghana Microfinance Policy.

The Ghana Microfinance Policy (GHAMP) reports that the national data and reporting systems, institutional data and clientele data are inadequate and weak in their 
dissemination within and between institutions. Overall, there is a paucity of information on microfinance institutions, their operations and their clients in the country and the attempt to develop a national data bank is yet to be fully realized. Developing countries' financial institutions, including those of Ghana, face various challenges in terms of reaching MSEs. They also operate within a limited infrastructure and a difficult business environment that is heightened when it comes to targeting MSEs. In Ghana, for instance, the minimum capital deposit requirements with the Central Bank make it difficult for microfinance institutions to expand their outreach and reach more MSEs. The Banking Law of 1989, which is silent on collateral confiscation in the case of default, makes lending more difficult to applicants who are conceived as riskier. All these issues contribute to the rationing problems in Ghana and in Africa in general.

The four major types of microfinance institutions in Ghana are rural and community banks, savings and loans companies, NGO-based institutions and governmentsponsored institutions.

Rural and community banks (RCBs) are the type of MFIs that operate as quasicommercial banks under the Banking Act, 783 of 2007. Their minimum requirement is GH\$300,000.00 (US\$144,000.00), which is, however, lower than that of commercial banks and they are not permitted to undertake foreign exchange transactions. They are owned by members of the rural community through equity participation and are licensed. Perhaps this may be the reason for them having the lowest capital requirement among the MFIs. Their main objectives are to mobilize savings and provide loans within their operational areas (Addo, 1998). Over the past decade, RCBs have adopted a more commercial approach and have introduced innovative programs, often in collaboration with NGOs. Rural and community banks have a low capital base and this problem hinders 
their expansion and depth of outreach. They provide loans to clients who have either a current or a savings account, who are in a productive business or who need loans to meet certain expenditure requirements. They give priority to clients who reside and conduct business within the community. They provide both individual and group loans and repayments are mostly on a monthly or biweekly basis. Their loan sizes are tied to the repayment performance and the collateral provided. Their interest rates are the market rates but are sometimes lower, depending on the source of funding. Their loan screening techniques include project appraisal and character and business references (Adjei, 2010).

Savings and loans companies (SLCs) are the type of MFIs that are licensed and regulated by the Bank of Ghana. They emerged in 1993 when the non-banking law came into existence. They are, however, restricted to a limited range of services. Their main functions include deposit mobilization from the general public and extension of credit to clients in the form of loans. They are located in the urban centers of the country, where they provide services to the urban poor. Their main target clients are micro and small entrepreneurs as well as female traders. The growth of SLCs in Ghana is slow due to the inability of new entrants to meet the requirements set by the Bank of Ghana. Their minimum capital requirement is far higher than that of the RCBs and is pegged at GH\$15,000,000.00 (US\$7,200,000.00). They serve clients who normally hold either a current or a savings account and are in a productive business or a start-up. They provide loans to their clients with a monthly or biweekly pay-up period, depending on the nature of the business. The loan size also depends on the repayment performance and collateral type and their interest rates are at the market level. The loan screening techniques include the provision of business plans, project appraisals and character references. 
NGO-based MFIs are incorporated as companies limited by guarantee (not for profit) under the Company Code 1973 (Act 179). Their poverty focus enables most of them to provide multiple services to their clients, especially micro-credit and skill training. They are not licensed to take deposits from the general public and therefore rely on external funding (donor agencies). The minimum requirement set by the Bank of Ghana is GH\$500,000.00 (US\$240,000.00). Their operations are normally financed by donor agencies as well as managed funds from the Government and development partners, equity capital and loans from commercial banks (Adjei, 2010). Their poverty focus leads them to achieve relatively deep penetration to poor clients, adopting innovative microfinance methodologies. They serve clients with a current or a savings account, who are in a productive business, for start-up as well as to meet expenditure needs. The loan repayment periods are monthly or biweekly. They practice progressive lending and depend largely on the repayment performance. Their interest rates are also at the market rate but sometimes lower, depending on their source of funding. The loan screening is based on project appraisal and character and business references.

The government-sponsored MFI currently in operation is the Microfinance and Small Loan Centre (MASLOC). It is the apex body responsible for implementing the Government of Ghana's microfinance program targeted at reducing poverty and creating jobs and wealth. Most of their target clients are women, who are often rationed out of credit from the commercial banks, as well as youths, through the Ghana Youth Employment and Entrepreneurial Development Agency (GYEEDA). Established in 2006, MASLOC performs the function of holding in trust funds of the Government of Ghana and development partners for the purpose of administering micro- and small-scale credit programs as well as providing, managing and regulating approved funds for microfinance 
and small-scale credit loan schemes and programs. Because of the Government's policy of creating employment avenues for the unemployed, loans are normally given to individuals for start-up, mostly under the GYEEDA (Ghana Youth Employment and Entrepreneurial Development Agency) program. Apart from these people, women and youths are often the targets. Access to credit and rationing therefore favors women and youths in the government-sponsored microfinance schemes.

\section{Data}

The rationing processes that are followed by all four types of MFIs involve three stages, as observed by Lapar and Graham (1988). These involve having interactions with prospective loan applicants and assessing their business plan or visiting the business premises of applicants who are already in business to ascertain their creditworthiness. Applicants who are perceived to be very risky are turned down before the loan application process begins through the issuance of the loan application forms. The decision on whether to grant an applicant the full or a partially amount of the loan requested then depends on the information sought from the applicant via the application forms.

A total of 14 microfinance institutions were able to provide us with data on their borrowers. Of these, 3 were savings and loan companies, 1 was government-sponsored, 5 were from non-governmental organizations and 5 were community and rural banks. A total of 1,429 observations, being the number of granted loans (both partially and fully granted) from the microfinance institutions, were used for the study. The data collected on these 1,429 borrowers consist of information about the individual, firm and loan characteristics as well as their status with regard to being rationed or otherwise. This information was 
gleaned from the microfinance clients' database for the 2012/2013 financial year. Of these observations, 372 (26.03\%) correspond to the number of borrowers of the savings and loan companies, 127 (8.89\%) relate to the government-sponsored MFI, 512 (35.83\%) are from the NGO type and 418 (29.25) correspond to the rural and community banks.

It was not possible to collect data from the microfinance institutions on applicants who were turned down completely in the loan application process, as this took place through the interaction process and therefore no application forms were completed and no records were made.

It was also difficult to have a very large sample as some of the microfinance institutions were unwilling to provide information on their borrowers even though they had indicated their willingness to provide such information during the preliminary and feasibility study stages. The non-availability of credit bureaus in Ghana also made it difficult to obtain more MFIs' data and hence a larger sample. According to Ayeh (2013), the fiercely competitive nature of these microfinance institutions makes them unwilling to provide data and information on their clients and operations to their APEX body, the Ghana Microfinance Institutions Network (GHAMFIN), to enable it create a credit bureau for fear that a competitor may use such information for its counter benefit. The difficulty in accessing data from the government-sponsored microfinance scheme (MASLOC) was also due to the perception that successful applicants are members of the political party in power and therefore a change of the party in power would lead to the persecution of these applicants, as happened in 2009 during the change of government from the National Patriotic Party (NPP) to the National Democratic Congress (NDC). It is hoped that when the Right to Information Bill, which is currently before the Parliament of Ghana, is passed, 
it will make it easier to access such information and also contribute to the research growth and development of the country.

A total of 418 observations represented the number of applicants who applied for loans at the rural and community banks. Of these, 198 (47.37\%) were rationed. The number of female applicants was 261 (62.44\%), whilst 169 (40.43\%) were youths (based on the GYEEDA module). The percentage of females with respect to gender confirms the observation made that the clients of microfinance and microcredit are mostly women. The classification of applicants based on economic sectors shows that 171 (40.91\%) were from the commerce sector, $33(7.89 \%)$ were from the transport sector, 29 (6.94\%) were from the manufacturing sector, 169 (40.43\%) were from the agricultural sector and 16 (3.83\%) were from the service sector. With regard to the educational background of the applicants, 197 (47.13\%) had tertiary education, 99 (23.68\%) had secondary education, 86 (20.57\%) had primary education and $36(8.61 \%)$ had no formal education. The number of applicants with non-mandatory savings was 376 (89.95\%).

In our data, 127 borrowers applied for loans from the government-sponsored microfinance scheme. Of this number, 65 (51.18\%) were rationed. Of the total number of applicants, 106 (83.46\%) were female, which again confirms that the majority of microfinance and microcredit clients are women. It also confirms the priority given to women in the government microfinance scheme. Of the total number of applicants, 54 (42.52\%) were youths. With regard to the economic sectors, 39 (30.71\%) were from the commerce sector, 7 (5.51\%) were from the transport sector, 18 (14.17\%) were from the manufacturing sector, 47 (37.01\%) were from the agricultural sector and 16 (12.6\%) were from the service sector. With respect to the educational background of the applicants to the government-sponsored scheme, 57 (44.88\%) had tertiary education, 21 (16.54\%) had 
secondary education, 49 (38.58\%) had primary education and none had no formal education. All the applicants had non-mandatory savings. It must be emphasized that the record keeping and disclosure of records on applicants have become difficult due to the fear of political witch-hunting as well as forcing them to pay up the loan even when the repayment period is not due, especially for applicants believed to be sympathizers with the then ruling government when there is a change of government to a different political party.

The number of applications for loans in the NGO type was 512. Of these, 146 (28.52\%) were rationed. Of the total number of applicants, 229 (44.73\%) were female whilst 178 (34.77\%) were youths. The applicants from the commerce sector accounted for 151 individuals (29.49\%), the transport sector accounted for 27 (5.27\%), 115 (22.46\%) were from the manufacturing sector, 104 (20.31\%) represented the agricultural sector and 115 (22.46\%) were from the service sector. With regard to the educational background of the applicants, 217 (42.38\%) had tertiary education, 149 (29.1\%) had up to secondary education, 140 (27.34\%) had up to primary education and 6 (1.17\%) had no formal education. Of the total number of applicants, 398 (77.73\%) had non-mandatory savings.

Finally, 372 individuals applied for loans from the savings and loan microfinance companies. Of these, 108 (29.03\%) were rationed. Of the total number of applicants, 211 (56\%) were female, again confirming the observation made that the majority of microfinance and microcredit clients are women. The total number of applicants who were youths was 151 (40.59\%). With regard to the economic sector of the applicants, 171 (46.77\%) were applicants from the commerce sector, 16 (4.3\%) were from the transport sector, $29(7.80 \%)$ were from the manufacturing sector, 77 (20.70\%) were from the agricultural sector and 76 (20.43\%) were from the service sector. Of the total number of applicants, 364 (97.85\%) had non-mandatory savings. 
The table below presents the descriptive analysis of the total number of applicants used for the study. The table shows that of the 1,429 applicants, 517 (36.18\%) were rationed, whilst 912 (63.82) applicants received the entire amount that they requested. Of the 1429 borrowers, 966 (67.60) were youths aged between 18 and 35 based on the GYEEDA module. Female borrowers made up 56.47\% (807) and this number also confirms that the clients of microfinance and microcredit are mostly women. The classification of borrowers based on economic sectors shows that 535 (37\%) were in the commerce sector, $83(6 \%)$ were in the transport sector, 191 (13\%) were in the manufacturing, $223(16 \%)$ were in the service sector and 397 (28\%) were from the agricultural sector. The large number of clients representing the commerce and agricultural sectors also supports the claim that the microfinance sector has a large number of female clients who are basically petty traders and a large number of clients from the agricultural sector, who normally need small loans for their operations. Borrowers in the manufacturing and transport sectors normally demand large sums of money and therefore turn to the formal financial sector, normally commercial banks, for loans. With regard to the educational background of the borrowers, 714 (50\%) were clients who had attained some tertiary education, 299 (21\%) had attained secondary education, $367(26 \%)$ had attained primary education and $49(3 \%)$ had not attained any formal education. The statistics on the educational background are slightly surprising since it was expected that a large number would be borrowers who had attained secondary and primary education. The microfinance sector is supposed to serve the vulnerable, who are often termed semi-literate people who are frequently turned down by formal commercial banks as they basically serve clients who have tertiary qualifications who are capable of preparing and keeping good financial records. The large number of borrowers who have attained tertiary education indicates the extent of rationing in the formal financial sector as well as the progress with which Ghana is making tertiary 
education accessible, as witnessed by the large number of private universities being established in the country. With regard to the closeness of borrowers to the microfinance institutions to which they applied for loans, 914 (63\%) were borrowers who were located within the district in which the microfinance institution operates, whilst 515 (36.04\%) were borrowers who were located outside the district within which the microfinance institution operates.

[Table 1, here]

\section{Econometric Estimation}

We assume that the microfinance type influencing the credit rationing and the factors influencing the credit-rationing behavior of the microfinance institutions are determined by the following linear relationships:

$$
\mathrm{y}_{\mathrm{i}}=\beta^{\prime} \mathrm{X}_{\mathrm{i}}+\varepsilon_{\mathrm{i}}
$$

In equation (1), we consider two outcomes. In one regression, the outcome $y_{i}$ is a dummy variable that takes the value one if the loan amount requested is not fully granted and zero otherwise. That is, with the binary outcome variable in model (1), we estimate the probability of being credit rationed. In this case, we resort to the probit model. The second regression considers the outcome $\mathrm{y}_{\mathrm{i}}$ to be the share of the total amount requested that has been granted. In this case, we estimate equation (1) using the OLS estimation method. The matrix X contains a set of individual characteristics and variables picking up the creditworthiness of the loan, that is, the microfinance type and the borrower's individual 
characteristics. These variables concern the borrower's economic and financial characteristics, the trust variables and the loan characteristic variables. $\beta$ is a vector of parameters to be estimated and $\varepsilon$ is random error term with the standard distributional properties in each case.

\subsection{The Probability of Being Credit Rationed}

In table 2, we show the estimated effects of the determinants of the probability of being credit rationed. To allow for interpretation and comparison across alternative models, we report the marginal effects instead of the estimated coefficients. The degree/percentage of the rationing and the direction will be determined by the marginal effects and their signs, whilst the significance or otherwise will be determined by their corresponding p-values. Our estimation strategy consists of introducing each set of variables sequentially. We start with the most parsimonious model, which only includes a set of dummy variables identifying the type of microfinance institution (column 1). In column 2, we add the individual and credit characteristics. Finally, in column 3, we include the monthly interest rate associated with each loan, which varies not only across borrowers but only across microfinance institutions. In columns 4, 5 and 6, we repeat the same sequential procedure, but now we include dummies for each microfinance institution (lender) instead of the type of microfinance institution to test whether within each institution type we can observe some heterogeneity across microfinance institutions regarding the amount of borrowers who are credit rationed. 
Our general results support the existing theory and other empirical studies, since all our control variables behave according to expectations. Having a relatively high number of years of experience, some relationship with the lender, being in the manufacturing sector and mandatory savings reduce the likelihood of being credit rationed and increase access to credit. On the contrary, having no formal education in relation to tertiary education, providing a guarantor and being in the Agriculture sector increases the likelihood of being credit rationed. Obviously, the need for a guarantor indicates that the loan might be risky. We find striking that being a female and a young entrepreneur rather reduce the likelihood of being credit rationed which do not support theory and other empirical studies in different countries. We think that this result might be due to the Ghana government's efforts at making access to credit to the marginalized and the vulnerable a priority through its Ghana Microfinance Policy.

We start commenting on the results of the models considering dummies for the type of microfinance institution. The government-sponsored microfinance institution type is set as the base category. The results in column (1) of table 2 indicate that the savings and loans microfinance type reduces rationing by $20 \%$, whilst the NGO type reduces rationing by $21 \%$, according to their marginal effects, with the rural and community bank type not showing any significance. The results above show that the government-sponsored type rather increases rationing. In column (2), we observe some individual and loan characteristics that are significant in determining rationing but the degree of rationing by the microfinance types does not change significantly, as indicated by their corresponding marginal effects. It is interesting and pertinent to perform a simulation; combining the interest rate as an explanatory variable with the microfinance type and individual and loan characteristics as in column (3), we observe that the marginal effects for all the 
microfinance types change sign from negative to positive and have much higher rates (marginal effects), as the savings and loans type increases rationing by $43 \%$, the NGO type increases it by $58 \%$ and the rural and community bank type increases it by $66 \%$ in the same way as the base category, being the government-sponsored type. The results in column (3) therefore indicate that the interest rate as a risk minimizing factor is very important in determining credit rationing and that all the microfinance types use interest rates to ration credit.

The results in column (4) indicate the rationing behavior of the various microfinance institutions under the four microfinance types with the governmentsponsored type as the base category. Their marginal effects show that the various microfinance institutions reduce rationing but at varied degrees even within each type and in relation to the base category, which rather increases rationing. It is interesting to note that the variations in the rationing behavior of these microfinance institutions are not according to their microfinance types. In column (5), we introduce individual and loan characteristics into the model with the microfinance institutions using the governmentsponsored type as the base category. Just like the results obtained in column (2), we do not find any significant change in the rationing behaviors of the microfinance institutions as indicated by their marginal effects; however, we find some individual and loan characteristics that are significant in determining rationing. An interesting simulation, again, is performed in column (6); after introducing interest rates into the model, some of the microfinance institutions increase rationing as the signs of the marginal effects change from negative to positive. This observation lends support to Stiglitz and Weiss's (1981) assertion that credit rationing may still persist even in the face of interest rate liberalization credit as lender will raise interest rates and ration credit and that it is the information provided by the borrowers that will determine credit rationing and access to 
credit. Our observation is that interest rates have rather worsen the rationing behavior of the microfinance companies and the likelihood of being less rationed is rather determined by the borrower and firm characteristics as well as the loan characteristics.

It is imperative to note that the rationing behaviors of the microfinance institutions differ even within the same type as there are some that behave just like the governmentsponsored type whilst others do not. The final result is that the rationing behavior is not influenced by the microfinance types but by the individual microfinance institutions.

[Table 2, here]

\subsection{The Size of the Credit Rationing}

Table 3 is a linear (OLS) estimation of the data to determine the percentage of the loan requested by borrowers that are conceded, that is, the size of the rationing. The degree/percentage of the credit access and the direction will be determined by the coefficients and their signs, whilst the significance or otherwise will be determined by their corresponding p-values. The results of this model are qualitatively the same as those for the probability of being rationed as the control variables behave in the same way as in our probit estimation and therefore lend support to theory and other empirical studies except for being female and young entrepreneur that goes contrary to theory and other empirical studies and the reasons, perhaps, is what we have attributed to in sub section (5.1). Column (1) of table 3 shows the results of the dummies for the microfinance types. Setting the government-sponsored type as the base category, we observe that the access to credit increases by $13 \%$ for the savings and loan type, $14 \%$ for the NGO type and $8 \%$ for the rural 
and community type, as indicated by their corresponding coefficients. In column (2), we observe that the increases in the access to credit by the various microfinance types do not show much difference when compared with those in column (1) when the individual, firm and loan characteristics are introduced into the model, as indicated by their corresponding coefficients, though we observe some significant variables with regard to the individual, firm and loan characteristics in determining the access to credit. It is important to note that in column (3), we do not observe any significance in the access to credit by all the microfinance types as we introduce the monthly interest rate into the model, though the various individual, firm and loan characteristics are still significant in determining it, as indicated by their significant p-values.

In columns (4), (5) and (6), we repeat the same procedure but we now include dummies for each microfinance institution instead of the dummies for the microfinance type, using the government-sponsored microfinance institution (MASLOC) as the base category, to test whether within each institution type we can observe some heterogeneity across the microfinance institutions regarding access to credit. A very important simulation is performed here; in column (6), we observe that some of the microfinance institutions reduce the access to credit at varied rates, as indicated by their corresponding coefficients across and within each type of institution as we introduce the monthly interest rate into the model, whilst we do not observe any significance with regard to access to credit for some of the microfinance institutions even within the same type, as indicated by their insignificant p-values. Our observation is that interest rates have rather reduced access to credit by the microfinance companies and access to credit is determined by the borrower and firm characteristics as well as the loan characteristics. We also observe some individual, firm and loan characteristics that are significant in determining access to credit. 
The final result is that access to credit is not influenced by the microfinance types but by the individual microfinance institutions.

[Table 3, here]

\section{Conclusions}

In this paper, we investigated the various microfinance types and the rationing behavior in the microfinance markets in Ghana. This research has become necessary and important since most research on credit rationing has not taken into consideration the fact that microfinance institutions have different policies, objectives and funding and therefore their rationing behavior may differ. We conclude that there is credit rationing in the microfinance market and that the rationing behavior is not influenced by the microfinance type but by the individual microfinance institutions. Our results also confirm what prevails in the microfinance markets in developing countries, where the rationing is influenced by the individual, firm, loan and borrower economic characteristics.

Ghana's financial liberalization policy, which includes interest rate liberalization for all forms of financial institutions and seeks to encourage financial institutions to lend to the private sector, especially micro and small-scale entrepreneurs, is exploitative and abusive as these lending institutions charge exorbitant interest rates on the loans granted to these vulnerable and frustrated entrepreneurs, who are often rationed out of credit by commercial banks. It also rather leads to some microfinance institutions folding as the default rates increase due to the fact that borrowers are unable to pay such huge interest rates. Our primary data show that MFIs charge very high interest rates between $24 \%$ and 
$60 \%$ per annum, which is a very disturbing development in the quest to make credit easily accessible to entrepreneurs who are desperate for loans because they are not served by commercial banks. The higher interest rates may defeat the policy intentions of the microfinance program, which mainly targets the poor and the marginalized. The interest rates liberalization that seeks to allocate credit at interest rates that reflects scarcities have rather worsen the rationing behavior of the microfinance companies as they tend to raise interest rates and rather increase rationing. There is a need for government intervention in this sector until such time that the microfinance sector is fully developed. Regulations through interest rate ceilings are necessary if more credit is to be extended to more micro and small businesses at affordable rates. The Financial Liberalization Policy is therefore not the best option for the microfinance sector in so far as the market is not competitive enough and rationing persists.

Ghana, through the Bank of Ghana's capital requirement policy, which sets different minimum capital requirements for each type of microfinance institution, is also not moving in the right direction, as our results show that the rationing behavior is not determined by the microfinance types but by the individual microfinance institutions. Setting a minimal and a fixed amount as capital requirements for all microfinance types will make more funds available, which will increase microfinance institutions' outreach and allow them to serve more clients who are vulnerable, desperate and unable to access loans from commercial banks. This will also promote the growth of the microfinance sector and enable it to become more competitive. The minimum capital requirements set for the various microfinance types are therefore not appropriate, as they tend to stifle the growth of the microfinance market, making it uncompetitive and unable to increase its outreach and meet the demands of the large number of micro and small-scale entrepreneurs. 
Microfinance institutions should also consider economic factors rather than using individual characteristics and other discriminating factors that are non-business-related as well as improving their monitoring systems as a way of minimizing and eliminating credit default. 


\section{References}

Addo, J.S. (1998) Feasibility and Business Plan for the Establishment of an ARB Apex Bank, Accra. Association of Rural Banks, Accra, Ghana

Adjei, J.K. (2010) Microfinance and Poverty Reduction: The Experience of Ghana. Bold Communications Limited, Accra.

Ahiawodzi, A. K., and Sackey, F. G., (2010). Determinants of Credit Rationing to the Private Sector in Ghana. African Journal of Business and Management. Vol 7 (38). Pp 3864-3874.

Agier, I., Guerin, I., and Szafarz, A., (2012). Child Gender and Parental Borrowing: Evidence from India. Economic Letters, 115, pp 363-365

Akoten J.E., Sawada, Y., and Otsuka, K., (2006). The Determinants of Credit Access and its Impacts on Micro and Small Enterprises: The Case of Garment Producers in Kenya. Economic Development and Cultural Change. Vol. 54. No. 4 pp 924-944.

Ana, K., and Roberto, E., (2011). Credit Rationing in Financial Distress: Croatia SMEs Finance Approach. International Journal of Law and Management. Vol 53 No. 1, pp62-84

Aquire, S. M., and Prosser, T (2011) Micro Credit Strategies and Funding: Lending to Sustainable Development? Financial Institutions for the Rural Poor in Bangladesh: An Institutional- and Household-Level Analysis. Washington, DC: International Food and Policy Research Institute (IFPRI). 
Armstrong, A., Davis, P.E., Liadze, L., and Rienzo, C., (2013). Evaluating Changes in Banking Lending to UK SMEs over 2001-12. Ongoing Tight Credit? Department for Business and Innovation and Skills. London.

Aryeetey, E. (ed.) (2000). Economic Reforms in Ghana: The Miracle and the Mirage. Accra: Woeli Publishing Services.

Atieno, R. (2001) Formal and Informal Institutions' Lending Policies and Access to Credit bySmall -Scale Entrepreneurs in Kenya: An Empirical Assessment. African Economic Research Consortium, Nairobi, Kenya.

Atzeni, G. and Piga, C. (2005): R\&D Investment, Credit Rationing and Sample Selection. International Industrial Organization Society Conference. Chicago.

Ayeh, O.R., (2012). Comprehensive Microfinance in Ghana: A hope for the poor. Dots Concept Limited, Accra.

Bank of Ghana (2007). A Note on Microfinance in Ghana. Research Department. Working Paper Series. WP/BOG-07/O1

Bank of Ghana (2012). Register of Microfinance as at October 2012. www.bog.gov.gh/privatecontent/Banking_Supervision/register of microfinance institutions as of October 2012.pdf

Becheti,L. Melody Garcia, M. and Giovanni Trovato, G. (2009) Credit Rationing and Credit view: Empirical Evidence from Loan Date. Credit for Economic and International Studies Research Paper Series Vol 17 issue 2, No 144, pp 206-227

Berger, A.N and Udell, F.G. (1999) Some Evidences on the Empirical Significance of Credit Rationing. Faculty Publication No.10-1-1992. University of South Carolina. 
Besley, T. (1994). "Savings, Credit, and Insurance", in Chenery H. and Srinivasan, T.N., eds., Handbook of Development of Economics 3. Amsterdam, Holland.

Bester, H. (1985) "Screening vs. Rationing in Credit Markets with Imperfect Information." American Economic Review Vol. 75. Pp 850-55.

Blumberg, B.F., and Latterie, W.A., (2008). Business Starters and Credit Rationing. Small Business Economics. Vol. 30 pp 187-200.

Boot, A. W. A., and Thakor, A. V. (1989) "Dynamic Equilibrium in a Competitive Credit Market: Intertemporal Contracting as Insurance against Rationing." Working Paper. Bloomington: Indiana Univ.

Carbo-Valverde, S., Degryse, H., and Rodriguez-Fernandes, F (2011). Lending Relationships and Credit Rating: The Impact of Securitization. 24 ${ }^{\text {th }}$ Australian Finance and Banking Conference Paper

Chakravarty, S and Abu, Z. S. (2010) Relationship Banking in Micro Credit: Evidence from Bangladesh. Purdue University.

Chakravarty, S. (2002) Relationship and Rationing in Consumer Loans: "Evidence from the Nineties." Purdue University of Economics Working Papers 1153, Purdue University. Department of Economics

Chan, Y., and Kanatas, G. (1985). Asymmetric valuations and the role of Collateral in Loan Agreements. Journal of Money, Credit and Banking, 17(1):84-95.

Doan, T.T (2010). Impacts of Household Credit on the Poor in Peri-Urban Areas of Ho Chi Minh, Vietnam. University of Waikato Research Commons. Available at: http://researchcommons.waikato.ac.nz/handle/10289/5165 
Duong, Ph. B. and Izumida, Y. (2002) Rural Development Finance in Viet Nam: a Microeconometric Analysis of Household Surveys. World Development, Vol. 30, no. 2, pp 319-335

Economic Reforms in Ghana: The Miracle and the Mirage. Aryeetey, E. (ed.) (2000). Accra: Woeli Publishing Services.

Ghana Microfinance Network (GHAMFIN) (2011) Performance Benchmarks of Microfinance Institutions in Ghana, Accra

Ghana Statistical Service (GSS) (2007b). Patterns and Trends of Poverty in Ghana, 19912006, Republic of Ghana, Accra.

Hardy, D. C., Holden, P. and Prokopenko, v. (2002) Microfinance Institutions and Public Policy. IMF Working Paper, wp/o2/159. Washington.

Jaffee, D. M. and Thomas R., (1976). 'Imperfect Information Uncertainty and Credit Rationing'. Quarterly Journal of Economics, Vol, 90. (Pp.651-66).

Jimenez, G and Saurina, J. (2003), Collateral, Type of Lender and Relationship Banking as Determinants of credit Risk. Bank of Spain.

Kaboski, J.P. and Townsend, R.M. (2005) Policies and Impact: An Analysis of Village Level Microfinance Institutions. Journal of the European Economic Association. Vol 3, No. 1 pp1-50

Kedir, A. (2000). Determinants of Access to Credit and Loan Amount: Household Evidence from Urban Ethiopia. Proceedings of the International Conference on Development Studies in Ethiopia, July 2003. Adis Ababa, Ethiopia. 
Lapar, M.L.A. and D.H. Graham (1988), “Credit Rationing Under a Deregulated Financial System” Working Paper Series No. 88 - 19

Lawal J. O., Monona B.T., Adjani O.I.Y., and Joni O. A. (2009): Determinants of Constraints to Credit Access among Cocoa Farming Households in Osun State Nigeria. Pakistan Journal of Social Sciences. Vol.6(3), pp 159-163

McKinnon, R.I. (1973). Money and Capital in Economic Development. Washington D.C.: The Bookings Institute.

Microfinance Information Exchange Inc (MIX) Report, 2011

Nguyen, C.H. (2007). "Determinants of Credit Participation and Its Impact on Household Consumption: Evidence From Rural Vietnam," CERT Discussion Papers 0703, Centre for Economic Reform and Transformation, Heriot Watt University.

Nuryartono, N., Schwarze, S and Zeller, M. (2005) Credit Rationing of Farm Households and Agricultural Production: Empirical evidence in the Rural Areas of Central Sulawesi Province of Indonessia. Conference on International Agricultural Research for Development. Tropentag

Okerenta, S.I and Orebiyi, J.S. (2005) Determinant of Agricultural Credit Supply to Farmers in the Nigeria Delta Area of Nigeria. Journal of Agriculture and Social Research Vol. 5 No.1, pp 67-72

Petrick, M. (2005) A Microeconometric Analysis of Credit Rationing in the Polish Farm Sector. European Review of Agricultural Economics Vol. 31 Issue1. Pp 77-101. Oxford University Press 
Rahji, M.A.Y and Fakayode, S.B. (2009) A Multinomial Logit Analysis of Agricultural Credit Rationing by Commercial Banks in Nigeria. International Research Journal of Finance and Economics. Issue 24, pp 90-99

Republic of Ghana. Ghana Microfinance Policy (2006). Accra, Ghana.

Riley, J. (1987) An Introduction to the Theory of Contests. No. 469, UCLA Economics Working Papers, UCL Department of Economics.

Schmidt, R.H. and Kropp, E. (1987). 'Rural Finance Guiding Principles', GTZ, Eschborn. Shaw, E.S. (1973). Financial Deepening in Economic Development. New York: Oxford University Press.

Sopfianos, G., Wachtel, P., Melnik, A., (1990). Loan Commitments and Monetary Policy. Journal of Banking and Finance. Vol. 14 (4) pp677-689.

Steijvers, T. (2008) Existence of Credit Rationing for SME's in the Belgian Corporate Bank Loan Market. Available at SSRN: http://ssrn.com/abstract $=495162$ or http://dx.doi.org/10.2139/ssrn.495162

Stiglitz, J. E. and Weiss, A. (1987) Credit Rationing: Reply. The American Economic Review. Vol 77 Issue 1 (Mar, 1987), (pp 228-231)

Stiglitz, J. E. and Weiss, A. (1981) 'Credit Ration in Markets with Imperfect Information', American Economic Review, Vol.71, No.3, June, (pp.393-410).

Subbotin, A. (2005). Determinant of Credit Rationing for Corporate Farms in Russia. European Annunciation of Agriculture Economics. X1th. Congress Copenhagen Denmark. 
The 1989 Banking Law of Ghana (Decree 225). Republic of Ghana.

The Banking Act of 1970. Republic of Ghana.

The Ghana Investment Promotion Act of 1994. Republic of Ghana.

UN (2011) Microfinance: What Role in Africa's Development? Africa Renewal Online. Available at; $\quad$ http://www.un.org/africarenewal/magazine/august2011/microfinance-what-role-africas-development

Von Pischke, J.D., (2008). Ghnadi vs Gauss: Ethical Issues in Micro and Small Business Finance. Vol 32. No. 3 pp 127-152.

World Bank (2000). World Development Report 2000/2001: Attracting Poverty. IBRD/World Bank. New York: Oxford University Press.

Zeller, M., (1994). Determinants of Credit Rationing: A Study of Informal Lenders and Formal Credit Groups in Madagascar. World Development Report Vol.22, No.12 (pp47-60)

Zeller, M and Meyer L. R. (2002). The Triangle of Microfinance- Financial Sustainability, Outreach and Impact, IFPRI, Washington \& The Johns Hopkins University Press: Maryland. 
Table 1: Descriptive Analysis of Data

\begin{tabular}{|c|c|c|c|c|c|}
\hline Variable & Description & \multicolumn{2}{|c|}{ Mode of measurement } & Mean & $\begin{array}{l}\text { Standard } \\
\text { deviation }\end{array}$ \\
\hline $\begin{array}{l}\text { Amount } \\
\text { requested }\end{array}$ & $\begin{array}{l}\text { Amount of money } \\
\text { requested }\end{array}$ & \multicolumn{2}{|l|}{ Ghana Cedis } & $4425 \cdot 36$ & 5389.37 \\
\hline $\begin{array}{l}\text { Amount } \\
\text { granted }\end{array}$ & $\begin{array}{l}\text { Amount of money } \\
\text { granted }\end{array}$ & \multicolumn{2}{|l|}{ Ghana Cedis } & 3652.09 & 4318.83 \\
\hline Education & $\begin{array}{l}\text { Borrower's } \\
\text { educational level }\end{array}$ & $\begin{array}{ll}\text { education } & \mathrm{p} \\
\text { tertiary } & 50 \\
\text { Secondary } & 21 \\
\text { elementary } & 26 \\
\text { illiterate } & 3\end{array}$ & $\begin{array}{l}\text { percentage } \\
50 \\
21 \\
26 \\
3\end{array}$ & 1.82 & .93 \\
\hline Sector & $\begin{array}{l}\text { The business sector } \\
\text { of the borrower }\end{array}$ & $\begin{array}{l}\text { sector } \\
\text { commerce } \\
\text { transport } \\
\text { manufacturing } \\
\text { agric } \\
\text { service }\end{array}$ & $\begin{array}{l}\text { percentage } \\
37 \\
6 \\
13 \\
28 \\
16 \\
\end{array}$ & 2.78 & 1.55 \\
\hline Sex & Sex of the borrower & $\begin{array}{l}1=\text { female } \\
0=\text { male }\end{array}$ & & .56 & .49 \\
\hline $\begin{array}{l}\text { Profits } \\
\text { Assets }\end{array}$ & $\begin{array}{l}\text { Profits after tax, } \\
\text { Borrower's Assets }\end{array}$ & $\begin{array}{l}\text { Ghana Cedis } \\
\text { Ghana Cedis }\end{array}$ & & $\begin{array}{l}899.44 \\
7020.34\end{array}$ & $\begin{array}{l}1643 \cdot 74 \\
12932.87\end{array}$ \\
\hline Age & Borrower's Age & Years & & 38.75 & 8.43 \\
\hline
\end{tabular}


Table 2: Credit Rationing and Microfinance Type: Probit Estimation with Marginal Effects

\begin{tabular}{|c|c|c|c|c|c|c|}
\hline & $\begin{array}{c}(1) \\
\text { Ration }\end{array}$ & $\begin{array}{c}(2) \\
\text { Ration } \\
\end{array}$ & $\begin{array}{c}\text { (3) } \\
\text { Ration }\end{array}$ & $\begin{array}{c}(4) \\
\text { Ration } \\
\end{array}$ & $\begin{array}{c}(5) \\
\text { Ration } \\
\end{array}$ & $\begin{array}{c}(6) \\
\text { Ration } \\
\end{array}$ \\
\hline Savings \& loans & $\begin{array}{c}-0.202^{* * *} \\
(0.041)\end{array}$ & $\begin{array}{c}-0.237^{* * * *} \\
(0.043)\end{array}$ & $\begin{array}{c}0.432^{* * * *} \\
(0.147)\end{array}$ & & & \\
\hline NGO type & $\begin{array}{c}-0.213^{* * *} \\
(0.042)\end{array}$ & $\begin{array}{c}-0.226^{* * *} \\
(0.048)\end{array}$ & $\begin{array}{c}0.585^{* * * *} \\
(0.150)\end{array}$ & & & \\
\hline Rural \& Comm. & $\begin{array}{l}-0.035 \\
(0.047)\end{array}$ & $\begin{array}{l}-0.054 \\
(0.052)\end{array}$ & $\begin{array}{c}0.658^{* * *} \\
(0.118)\end{array}$ & & & \\
\hline Maturity & & $\begin{array}{l}0.018 * * * \\
(0.003)\end{array}$ & $\begin{array}{c}0.019^{* * *} \\
(0.003)\end{array}$ & & $\begin{array}{c}0.021^{* * *} \\
(0.003)\end{array}$ & $\begin{array}{l}0.021^{* * *} \\
(0.003)\end{array}$ \\
\hline Assets value & & $\begin{array}{l}-0.000 \\
(0.000)\end{array}$ & $\begin{array}{l}-0.000 \\
(0.000)\end{array}$ & & $\begin{array}{c}-0.000 \\
(0.000)\end{array}$ & $\begin{array}{c}-0.000 \\
(0.000)\end{array}$ \\
\hline Profits & & $\begin{array}{c}0.000 \\
(0.000)\end{array}$ & $\begin{array}{c}0.000 \\
(0.000)\end{array}$ & & $\begin{array}{c}0.000 \\
(0.000)\end{array}$ & $\begin{array}{c}0.000 \\
(0.000)\end{array}$ \\
\hline Experience & & $\begin{array}{c}-0.014^{* * *} \\
(0.003)\end{array}$ & $\begin{array}{c}-0.014^{* * *} \\
(0.003)\end{array}$ & & $\begin{array}{c}-0.013^{* * *} \\
(0.004)\end{array}$ & $\begin{array}{c}-0.013^{* * *} \\
(0.004)\end{array}$ \\
\hline Second Cycle & & $\begin{array}{c}0.025 \\
(0.041)\end{array}$ & $\begin{array}{c}0.030 \\
(0.042)\end{array}$ & & $\begin{array}{l}0.086^{*} \\
(0.046)\end{array}$ & $\begin{array}{l}0.086^{*} \\
(0.046)\end{array}$ \\
\hline Primary & & $\begin{array}{c}-0.054 \\
(0.037)\end{array}$ & $\begin{array}{c}-0.051 \\
(0.037)\end{array}$ & & $\begin{array}{l}-0.035 \\
(0.039)\end{array}$ & $\begin{array}{c}-0.035 \\
(0.039)\end{array}$ \\
\hline No Education & & $\begin{array}{c}0.434^{* * *} \\
(0.085)\end{array}$ & $\begin{array}{c}0.456^{* * * *} \\
(0.082)\end{array}$ & & $\begin{array}{c}0.463^{* * *} \\
(0.109)\end{array}$ & $\begin{array}{c}0.463^{* * *} \\
(0.109)\end{array}$ \\
\hline Female & & $\begin{array}{c}-0.106^{* * * *} \\
(0.029)\end{array}$ & $\begin{array}{c}-0.100^{* * * *} \\
(0.029)\end{array}$ & & $\begin{array}{c}-0.088^{* * * *} \\
(0.030)\end{array}$ & $\begin{array}{c}-0.088^{* * * *} \\
(0.030)\end{array}$ \\
\hline Youth & & $\begin{array}{c}-0.122^{* * *} \\
(0.028)\end{array}$ & $\begin{array}{c}-0.107^{* * *} \\
(0.029)\end{array}$ & & $\begin{array}{c}-0.122^{* * *} \\
(0.029)\end{array}$ & $\begin{array}{c}-0.122^{* * *} \\
(0.029)\end{array}$ \\
\hline Collateral & & $\begin{array}{c}0.000 \\
(0.000)\end{array}$ & $\begin{array}{c}0.000 \\
(0.000)\end{array}$ & & $\begin{array}{c}0.000 \\
(0.000)\end{array}$ & $\begin{array}{c}0.000 \\
(0.000)\end{array}$ \\
\hline Location & & $\begin{array}{c}0.029 \\
(0.029)\end{array}$ & $\begin{array}{c}0.046 \\
(0.030)\end{array}$ & & $\begin{array}{c}0.044 \\
(0.030)\end{array}$ & $\begin{array}{c}0.044 \\
(0.030)\end{array}$ \\
\hline Guarantor & & $\begin{array}{l}0.318^{* * * *} \\
(0.035)\end{array}$ & $\begin{array}{l}0.281^{* * *} \\
(0.036)\end{array}$ & & $\begin{array}{c}0.266^{* * *} \\
(0.043)\end{array}$ & $\begin{array}{l}0.266^{* * * *} \\
(0.043)\end{array}$ \\
\hline Relationship & & $\begin{array}{c}-0.108^{* * *} \\
(0.028)\end{array}$ & $\begin{array}{c}-0.102^{* * *} \\
(0.028)\end{array}$ & & $\begin{array}{c}-0.121^{* * *} \\
(0.029)\end{array}$ & $\begin{array}{c}-0.121^{* * * *} \\
(0.029)\end{array}$ \\
\hline Purpose & & $\begin{array}{c}-0.031 \\
(0.031)\end{array}$ & $\begin{array}{c}-0.021 \\
(0.032)\end{array}$ & & $\begin{array}{c}-0.026 \\
(0.032)\end{array}$ & $\begin{array}{c}-0.026 \\
(0.032)\end{array}$ \\
\hline Transport & & $\begin{array}{c}-0.015 \\
(0.062)\end{array}$ & $\begin{array}{c}-0.014 \\
(0.062)\end{array}$ & & $\begin{array}{l}-0.030 \\
(0.063)\end{array}$ & $\begin{array}{l}-0.030 \\
(0.063)\end{array}$ \\
\hline Manufacturing & & $\begin{array}{l}-0.062 \\
(0.047)\end{array}$ & $\begin{array}{l}-0.080^{*} \\
(0.047)\end{array}$ & & $\begin{array}{c}-0.104^{* *} \\
(0.047)\end{array}$ & $\begin{array}{l}-0.104^{* *} \\
(0.047)\end{array}$ \\
\hline Agric & & $\begin{array}{l}0.171^{* * *} \\
(0.044)\end{array}$ & $\begin{array}{l}0.168^{* * *} \\
(0.044)\end{array}$ & & $\begin{array}{c}0.163^{* * * *} \\
(0.046)\end{array}$ & $\begin{array}{l}0.163^{* * *} \\
(0.046)\end{array}$ \\
\hline Service & & $\begin{array}{c}0.036 \\
(0.048)\end{array}$ & $\begin{array}{c}0.025 \\
(0.048)\end{array}$ & & $\begin{array}{c}0.037 \\
(0.050)\end{array}$ & $\begin{array}{c}0.037 \\
(0.050)\end{array}$ \\
\hline Savings & & $\begin{array}{c}-0.233^{* * *} \\
(0.045)\end{array}$ & $\begin{array}{c}-0.264^{* * *} \\
(0.041)\end{array}$ & & $\begin{array}{c}-0.228^{* * *} \\
(0.075)\end{array}$ & $\begin{array}{c}-0.228^{* * *} \\
(0.075)\end{array}$ \\
\hline
\end{tabular}




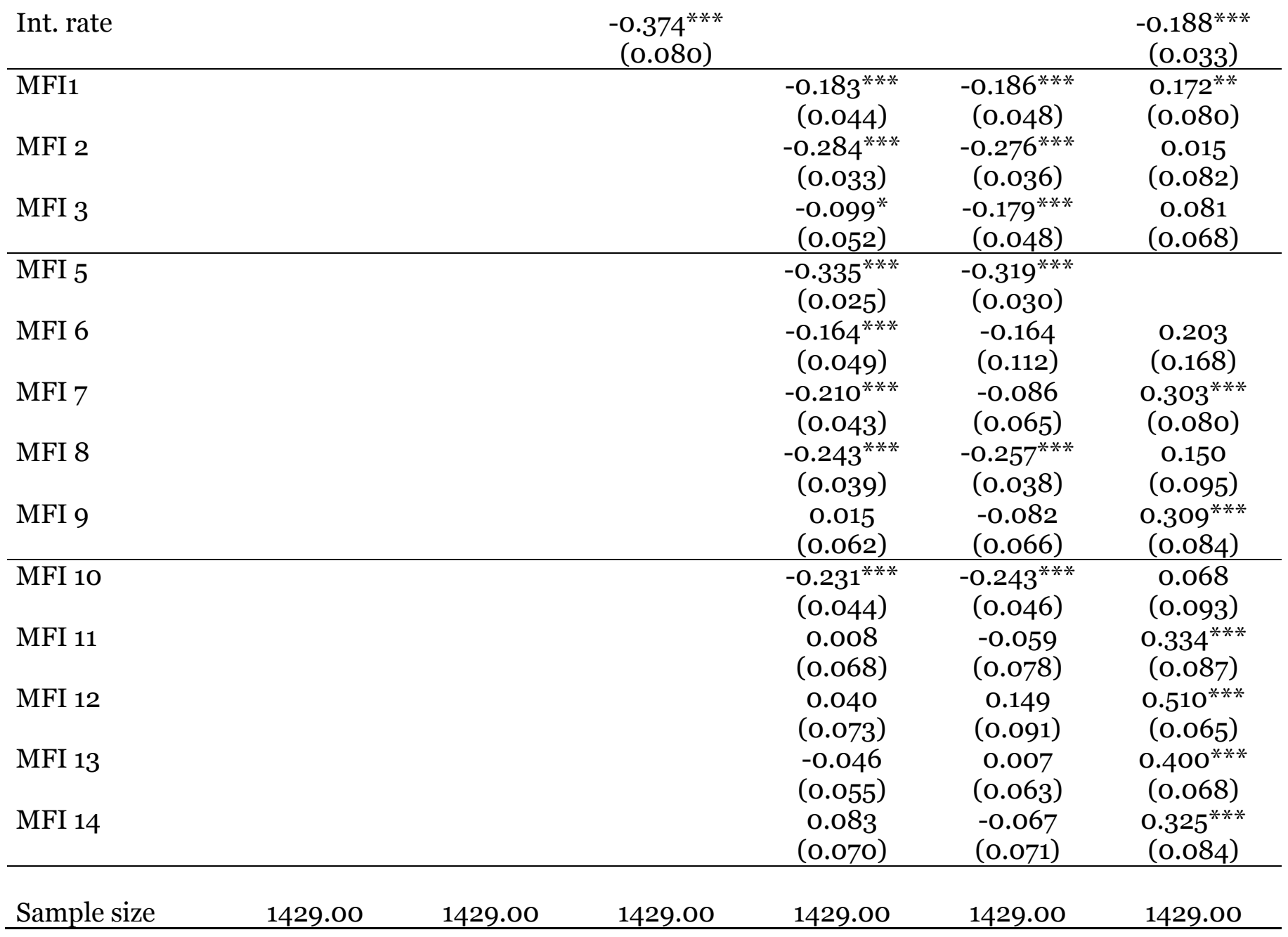


Table 3: Credit Rationing and Microfinance Type: Linear Regression

\begin{tabular}{|c|c|c|c|c|c|c|}
\hline & $\begin{array}{c}(1) \\
\text { Access }\end{array}$ & $\begin{array}{c}(2) \\
\text { Access }\end{array}$ & $\begin{array}{c}\text { (3) } \\
\text { Access }\end{array}$ & $\begin{array}{c}\text { (4) } \\
\text { Access }\end{array}$ & $\begin{array}{c}(5) \\
\text { Access }\end{array}$ & $\begin{array}{c}(6) \\
\text { Access }\end{array}$ \\
\hline Savings \& loans & $\begin{array}{c}0.136^{* * *} \\
(0.019)\end{array}$ & $\begin{array}{c}0.145^{* * *} \\
(0.019)\end{array}$ & $\begin{array}{l}-0.039 \\
(0.054)\end{array}$ & & & \\
\hline NGO type & $\begin{array}{c}0.142^{* * * *} \\
(0.018)\end{array}$ & $\begin{array}{c}0.148^{* * * *} \\
(0.019)\end{array}$ & $\begin{array}{l}-0.079 \\
(0.064)\end{array}$ & & & \\
\hline Rural \& Comm. & $\begin{array}{c}0.085^{* * * *} \\
(0.019)\end{array}$ & $\begin{array}{c}0.100^{* * * *} \\
(0.019)\end{array}$ & $\begin{array}{l}-0.102^{*} \\
(0.058)\end{array}$ & & & \\
\hline Maturity & & $\begin{array}{c}-0.004^{* * *} \\
(0.001)\end{array}$ & $\begin{array}{c}-0.005^{* * *} \\
(0.001)\end{array}$ & & $\begin{array}{c}-0.006^{* * *} \\
(0.001)\end{array}$ & $\begin{array}{c}-0.006^{* * *} \\
(0.001)\end{array}$ \\
\hline Assets value & & $\begin{array}{c}0.000 \\
(0.000)\end{array}$ & $\begin{array}{c}0.000 \\
(0.000)\end{array}$ & & $\begin{array}{c}0.000 \\
(0.000)\end{array}$ & $\begin{array}{c}0.000 \\
(0.000)\end{array}$ \\
\hline Profits & & $\begin{array}{c}-0.000 \\
(0.000)\end{array}$ & $\begin{array}{c}-0.000 \\
(0.000)\end{array}$ & & $\begin{array}{l}-0.000 \\
(0.000)\end{array}$ & $\begin{array}{l}-0.000 \\
(0.000)\end{array}$ \\
\hline Experience & & $\begin{array}{c}0.003^{* * *} \\
(0.001)\end{array}$ & $\begin{array}{l}0.003^{* *} \\
(0.001)\end{array}$ & & $\begin{array}{l}0.003^{* *} \\
(0.001)\end{array}$ & $\begin{array}{l}0.003^{* *} \\
(0.001)\end{array}$ \\
\hline Second Cycle & & $\begin{array}{l}-0.020 \\
(0.014)\end{array}$ & $\begin{array}{c}-0.022 \\
(0.014)\end{array}$ & & $\begin{array}{c}-0.039^{* * *} \\
(0.015)\end{array}$ & $\begin{array}{c}-0.039^{* * *} \\
(0.015)\end{array}$ \\
\hline Primary & & $\begin{array}{c}0.014 \\
(0.013)\end{array}$ & $\begin{array}{c}0.013 \\
(0.013)\end{array}$ & & $\begin{array}{c}0.004 \\
(0.013)\end{array}$ & $\begin{array}{c}0.004 \\
(0.013)\end{array}$ \\
\hline No Education & & $\begin{array}{c}-0.121^{* * *} \\
(0.032)\end{array}$ & $\begin{array}{c}-0.126^{* * *} \\
(0.032)\end{array}$ & & $\begin{array}{c}-0.119^{* * *} \\
(0.039)\end{array}$ & $\begin{array}{c}-0.119^{* * *} \\
(0.039)\end{array}$ \\
\hline Female & & $\begin{array}{c}0.031^{* * * *} \\
(0.010)\end{array}$ & $\begin{array}{c}0.029^{* * * *} \\
(0.010)\end{array}$ & & $\begin{array}{l}0.026^{* *} \\
(0.010)\end{array}$ & $\begin{array}{l}0.026^{* *} \\
(0.010)\end{array}$ \\
\hline Youth & & $\begin{array}{l}0.020^{* *} \\
(0.010)\end{array}$ & $\begin{array}{c}0.016 \\
(0.010)\end{array}$ & & $\begin{array}{l}0.023^{* *} \\
(0.010)\end{array}$ & $\begin{array}{l}0.023^{* *} \\
(0.010)\end{array}$ \\
\hline Collateral & & $\begin{array}{l}-0.000 \\
(0.000)\end{array}$ & $\begin{array}{l}-0.000 \\
(0.000)\end{array}$ & & $\begin{array}{l}-0.000 \\
(0.000)\end{array}$ & $\begin{array}{l}-0.000 \\
(0.000)\end{array}$ \\
\hline Location & & $\begin{array}{c}0.002 \\
(0.010)\end{array}$ & $\begin{array}{l}-0.003 \\
(0.010)\end{array}$ & & $\begin{array}{l}-0.003 \\
(0.010)\end{array}$ & $\begin{array}{l}-0.003 \\
(0.010)\end{array}$ \\
\hline Guarantor & & $\begin{array}{c}-0.096^{* * * *} \\
(0.012)\end{array}$ & $\begin{array}{c}-0.085^{* * *} \\
(0.012)\end{array}$ & & $\begin{array}{c}-0.079^{* * *} \\
(0.014)\end{array}$ & $\begin{array}{c}-0.079^{* * *} \\
(0.014)\end{array}$ \\
\hline Relationship & & $\begin{array}{c}0.028^{* * * *} \\
(0.010)\end{array}$ & $\begin{array}{c}0.026^{* * *} \\
(0.010)\end{array}$ & & $\begin{array}{c}0.033^{* * * *} \\
(0.009)\end{array}$ & $\begin{array}{c}0.033^{* * * *} \\
(0.009)\end{array}$ \\
\hline Purpose & & $\begin{array}{c}0.017 \\
(0.011)\end{array}$ & $\begin{array}{c}0.014 \\
(0.011)\end{array}$ & & $\begin{array}{c}0.015 \\
(0.011)\end{array}$ & $\begin{array}{c}0.015 \\
(0.011)\end{array}$ \\
\hline Transport & & $\begin{array}{c}-0.004 \\
(0.022)\end{array}$ & $\begin{array}{c}-0.003 \\
(0.022)\end{array}$ & & $\begin{array}{c}0.005 \\
(0.022)\end{array}$ & $\begin{array}{c}0.005 \\
(0.022)\end{array}$ \\
\hline Manufacturing & & $\begin{array}{c}0.036^{* *} \\
(0.017)\end{array}$ & $\begin{array}{c}0.043^{* *} \\
(0.017)\end{array}$ & & $\begin{array}{c}0.050^{* * *} \\
(0.018)\end{array}$ & $\begin{array}{c}0.050^{* * * *} \\
(0.018)\end{array}$ \\
\hline Agric & & $\begin{array}{c}-0.036^{* *} \\
(0.015)\end{array}$ & $\begin{array}{c}-0.035^{* *} \\
(0.015)\end{array}$ & & $\begin{array}{c}-0.028^{*} \\
(0.015)\end{array}$ & $\begin{array}{l}-0.028^{*} \\
(0.015)\end{array}$ \\
\hline Service & & $\begin{array}{c}-0.013 \\
(0.016)\end{array}$ & $\begin{array}{l}-0.009 \\
(0.016)\end{array}$ & & $\begin{array}{l}-0.009 \\
(0.016)\end{array}$ & $\begin{array}{l}-0.009 \\
(0.016)\end{array}$ \\
\hline Savings & & $\begin{array}{c}0.074^{* * * *} \\
(0.022)\end{array}$ & $\begin{array}{c}0.087^{* * *} \\
(0.022)\end{array}$ & & $\begin{array}{c}0.055 \\
(0.034)\end{array}$ & $\begin{array}{c}0.055 \\
(0.034)\end{array}$ \\
\hline Int. rate & & & $\begin{array}{c}0.100^{* * *} \\
(0.027)\end{array}$ & & & $\begin{array}{c}0.077^{* * *} \\
(0.010)\end{array}$ \\
\hline
\end{tabular}




\begin{tabular}{|c|c|c|c|c|c|c|}
\hline \multicolumn{4}{|l|}{ MFI1 } & $\begin{array}{c}0.129^{* * *} \\
(0.022)\end{array}$ & $\begin{array}{c}0.135^{* * *} \\
(0.023)\end{array}$ & $\begin{array}{l}-0.020 \\
(0.023)\end{array}$ \\
\hline \multirow{2}{*}{\multicolumn{4}{|c|}{ MFI 2}} & $0.162^{* * *}$ & $0.146^{* * *}$ & -0.009 \\
\hline & & & & $(0.023)$ & $(0.023)$ & (0.023) \\
\hline \multirow{2}{*}{\multicolumn{4}{|c|}{ MFI 3}} & $0.119^{* * *}$ & $0.147^{* * *}$ & 0.030 \\
\hline & & & & $(0.023)$ & $(0.023)$ & (0.021) \\
\hline \multirow{2}{*}{\multicolumn{4}{|c|}{ MFI 5}} & $0.197^{* * *}$ & $0.193^{* * *}$ & \\
\hline & & & & (0.024) & (0.025) & \\
\hline \multirow{2}{*}{\multicolumn{4}{|c|}{ MFI 6}} & $0.144^{* * *}$ & $0.155^{* * *}$ & 0.000 \\
\hline & & & & (0.024) & (0.048) & (0.050) \\
\hline \multirow{2}{*}{\multicolumn{4}{|c|}{ MFI 7}} & $0.146^{* * *}$ & $0.108 * * *$ & $-0.047^{* *}$ \\
\hline & & & & $(0.024)$ & (0.025) & $(0.024)$ \\
\hline \multirow{2}{*}{\multicolumn{4}{|c|}{ MFI 8}} & $0.190^{* * *}$ & $0.194^{* * *}$ & 0.001 \\
\hline & & & & $(0.024)$ & $(0.024)$ & $(0.026)$ \\
\hline \multirow{2}{*}{\multicolumn{4}{|c|}{ MFI 9}} & 0.036 & $0.076^{* * *}$ & $-0.078^{* * *}$ \\
\hline & & & & $(0.024)$ & $(0.026)$ & $(0.026)$ \\
\hline \multirow{2}{*}{\multicolumn{4}{|c|}{ MFI 10}} & $0.157^{* * *}$ & $0.162^{* * *}$ & 0.008 \\
\hline & & & & $(0.027)$ & $(0.027)$ & (0.026) \\
\hline \multirow{2}{*}{\multicolumn{4}{|c|}{ MFI 11}} & $0.087^{* * *}$ & $0.122^{* * *}$ & -0.033 \\
\hline & & & & $(0.026)$ & $(0.029)$ & $(0.027)$ \\
\hline \multirow{2}{*}{\multicolumn{4}{|c|}{ MFI 12}} & 0.026 & 0.004 & $-0.151^{* * *}$ \\
\hline & & & & (0.027) & (0.029) & (0.029) \\
\hline \multirow{2}{*}{\multicolumn{4}{|c|}{ MFI 13}} & $0.093^{* * *}$ & $0.082^{* * *}$ & $-0.073^{* * *}$ \\
\hline & & & & $(0.022)$ & $(0.022)$ & (0.022) \\
\hline \multirow{2}{*}{\multicolumn{4}{|c|}{ MFI 14}} & $0.057^{* *}$ & $0.109^{* * *}$ & $-0.046^{*}$ \\
\hline & & & & $(0.025)$ & $(0.026)$ & $(0.026)$ \\
\hline \multirow{2}{*}{ Constant } & $0.778 * * *$ & $0.773^{* * *}$ & $0.581^{* * *}$ & $0.778^{* * *}$ & $0.791^{* * *}$ & $0.636^{* * *}$ \\
\hline & (0.016) & (0.023) & (0.057) & (0.016) & $(0.023)$ & (0.037) \\
\hline R-squared & 0.051 & 0.143 & 0.151 & 0.101 & 0.179 & 0.179 \\
\hline Sample size & 1429.00 & 1429.00 & 1429.00 & 1429.00 & 1429.00 & 1429.00 \\
\hline
\end{tabular}

